\title{
Effect of accessibility and utilization of electronic information resources on productivity of academic staff in selected Nigerian universities
}

\author{
Okon E. Ani ${ }^{1}$, Patrick Ngulube ${ }^{2}$, Bosire Onyancha ${ }^{3}$ \\ ${ }^{1}$ Library Department, University of Calabar, Calabar, Nigeria \\ ${ }^{2}$ School of Interdisciplinary Research and Postgraduate Studies, University of South Africa, Pretoria, South Africa \\ ${ }^{3}$ Department of Information Science, University of South Africa, Pretoria, South Africa
}

\author{
Email address: \\ anioedet@yahoo.com (O. E. Ani)
}

\section{To cite this article:}

Okon E. Ani, Patrick Ngulube, Bosire Onyancha. Effect of Accessibility and Utilization of Electronic Information Resources on Productivity of Academic Staff in Selected Nigerian Universities. Science Research. Vol. 2, No. 6, 2014, pp. 166-171. doi: 10.11648/j.sr.20140206.13

\begin{abstract}
The aim of the paper was to investigate the effect of accessibility and utilization of electronic resources on productivity of academic staff in Nigerian universities. A survey method was used in the study, with a questionnaire as the instrument for data collection. Responses from 324 academic staff out of 586 that were surveyed were used for data analysis. Correlation analysis showed that, there was a positive correlation between accessibility and utilization of electronic resources on productivity of respondents in the survey $(r=0.135 ; \mathrm{p}=0.015)$. This implies that increase in access and use of e-resources will lead to increase in productivity among respondents at the surveyed universities. Similar result was obtained when the hypothesis was tested at international level with $\mathrm{r}=0.158$ and $\mathrm{p}=0.004$. In other words, respondents that access and use eresources in research frequently publish more articles in international journals than those who do not. It was recommended that, in view of the observed positive impact of e-resources on productivity in the survey; university managements, university librarians, National Universities Commission (NUC) and other stakeholders in Nigerian universities should intensify the process of effective information and communication technology (ICT) diffusion and provision of relevant e-resources in Nigerian universities towards qualitative research. This will also make academic staff in Nigerian universities to be globally competitive for journal space in international journals, and thus bridge the productivity gap between Nigeria and developed countries.
\end{abstract}

Keywords: Academic Staff, Electronic Resources, Information and Communication Technology, Nigerian Universities, Productivity, Research, Accessibility

\section{Introduction}

One of the basic goals of universities is to provide enabling environment for the conduct of research and dissemination of knowledge for societal/national development. Access to information is imperative to successful conduct of research in universities. Moon, Hossain, Kang and Shin (2012) in discussing the role of access to information in research, opined that access to relevant information is necessary for academic staff to take efficient decision in his/her research. This view is affirmed by Adeloye (2000: 282) that access and use of information is needed "for problem solving and decision making" in research process. Thus, Moon et al., (2012) used the term informatization to describe countries/institutions (universities) that provide wider access to information to aid research process. Hoq (2012) also viewed access and use of information as being vital in efficient research process. Aina (2012) in his discourse argued that access to information is critical in research in Africa. However, a report by Foster, Heppensta, Lazarz and Broug (2008) has revealed a low level of access and use of emerging electronic resources by academic staff in Nigerian universities which are critical to effective research in universities around the world. Foster et al. (2008) argued that inadequate access and use of electronic resources affects the publication outputs of Nigerian universities in international journals. Since, publication output of academic staff in Nigerian universities in international journals is reportedly low, and publication output is a major indicator of productivity; this implies that academic staff in 
Nigerian universities are not internationally productive.

Frankor and Akussah (2012: 32) affirmed that academic staff in Nigerian universities "had little access to relevant and reliable information when making decisions" on their research activities. With the emerging electronic information environment in universities characterized with integration of information and communication technologies (ICTs) in research process, the state of ICT infrastructures in Nigerian universities is reportedly low in comparison with that of universities in developed countries. In other words, Nigerian universities lack the capacity to invest in the emerging ICTs to support efficient research process. The consequence is that the degree of access and use of electronic resources is low among the academic staff in Nigerian universities. Since Nigerian universities are unable to provide equitable access to information and communication technologies (ICTs), particularly robust and reliable Internet connectivity, the global information resources, the effect of this seems to be lack of efficient access to information for research. The goal of this study is therefore to critically explore if academic staff in Nigerian universities with wider access and use of electronic resources are productive than those with low access and use of these resources in research.

\subsection{Electronic Information Resources}

Electronic information resources simply referred to as electronic resources or e-resources are information stored in electronic format in computer or computer related facilities (CD-ROMs, digital libraries or the Internet). Haridasan and Khan (2009: 118) defined electronic information resources as "resources in which information is stored electronically and which are accessible through electronic systems and networks". Electronic resources are now used to supplement printed information sources in the university libraries. Different types of electronic resources that are used in this study are: e-journals, e-books, online databases, electronic conference proceedings and CD-ROM databases (Appleton, 2006; Costa \& Meadows, 2000; Dadzie, 2005; Lee, 2002; Parameshwar \& Patil, 2009; Swain, 2010). Online databases that are commonly used by academic staff in Nigerian universities for their research are EBSCO HOST, AGORA, HINARI, MEDLINE, JSTOR and OARE. A number of these e-resources (online databases/digitized local journals) are accessible via the National Virtual Library (nigerianvirtuallibrary.com) which is run by National Universities Commission.

The major benefit of electronic resources in the university library besides ease of access to the needed information is that access can be done remotely by academic staff in their offices/laboratories or at homes without physical visit to the library. Thus, electronic resources promote efficiency in dissemination of information for research purposes in universities (Thanuskodi, 2012). Ellis and Oldman (2005: 35) opined that electronic resource "is more of a tool to assist in conducting research, a way of scanning a lot of materials quickly". The act of providing access to electronic resources by the university library to the patrons is referred to as electronic information services. Appleton (2006: 620) defined electronic information services as delivery of information tools/products to "requesting users electronically" usually by computer mediation.

In view of the potential advantages and benefits of eresources over the print in modern electronic information environment, accessibility and utilization of e-resources is fast becoming a norm in research in universities around the world. Hence, "access to electronically stored information in computers has been increasing regularly" in universities to aid academic staff in their research (Rubin, 2000: 11). Different types of electronic resources that are used in this study are: e-journals, e-books, online databases, electronic conference proceedings and CD-ROM databases (Appleton, 2006; Costa \& Meadows, 2000; Dadzie, 2005; Lee, 2002; Parameshwar \& Patil, 2009; Swain, 2010).

\subsection{Productivity}

Goel (2002) defined productivity as a number of articles published in standard journals within a period; and this is affirmed by Kirlidog and Bayir (2007) who described productivity as the measure of scientific publications which are published in prestigious journals. Usually, publications are classified into international (foreign) publications and national (local) publications (Ani, Esin \& Inyang, 2003; Collazo-Reyes, Luna-Morales, Russell \& Perez-Angon, 2011; Foster et al., 2008; Goel, 2002; Okafor, 2011; Sanz, Aragon \& Mendez, 1995). Academic staff in developing (African) countries preferably published in international journals due to their relative high visibility (Ani, Esin \& Inyang, 2003; Bottle, Hossein, Bottle, \& Adesanya, 1994; Sanz, Aragon \& Mendez, 1995), scholarly quality and to have international recognition in their disciplines/fields of specialization. International publication does not only benefit the individual academic staff, but the entire university, as publication output is one of the vital indicators use in global ranking of universities. This informed the reason why most scientists and science policy administrators or university managements in developing countries have preference for international publications (Goel, 2002). For example, Okafor (2011) reported that the management of the University of Agriculture Abeokuta, Nigeria requires that academic staff must have a certain number of international publications (articles in international journals) before being promoted to certain academic ranks, this is also true in respect of the University of Calabar, Nigeria for promotion to senior academic ranks in the university.

In Spain, Sanz, Aragon and Mendez (1995) similarly reported that publication of articles in international journals is often considered more significant by academic staff in Spanish universities than in national journals. A review by Sanz, Aragon and Mendez (1995) revealed the same patterns in India, Brazil and Croatia. The preference for publishing their research findings in international journals by scholars in developing (African) countries is essentially attributed to poor quality of national/local journals which resulted in inability of these papers to be cited internationally and thus 
not being indexed by scholarly databases, such as the Web of Science, or Scopus - popularly used to evaluate researchers and journals. According to Sanz, Aragon and Mendez (1995), national journals especially from developing (African) countries are usually not cited internationally because most of their publications are devoted to local problems which are of low interest to the international community.Thus, academic staff may be nationally or internationally productive, and the total number of publications therefore consists of the total number of articles in national and international journals (Duque et al., 2010). In other words, the total productivity of a given academic staff is a measure of the sum of his/her published articles in national and international journals.

In view of the low number of journal articles published in international journals, academics in Nigerian universities have been described as being less productive compared with their counterparts in developed nations. Observably, a number of factors have been identified to have effect on productivity of academic staff in Nigerian universities as well as in international perspective. These have been discussed by scholars to include: nature of research - basic or applied research (Al-Shanbari \& Meadows, 1995; Gupta, Kumar \& Aggarwal, 1999; Sanz, Aragon \& Mendez 1995), inadequate funding, lack of equipment/facilities, poor information infrastructure/communication network, working conditions, language, government policy, collaboration, journal's editor and referees, criteria for promotion of academic staff, number of information sources published in a country (Abrahams, Burke \& Mouton, 2009/2010; Nworgu, 1991; Onyancha, 2008), and low accessibility and utilization of electronic resources (Foster et al., 2008). However, accessibility and utilization of e-resources has been the factor of interest in the present study, since it is postulated by Foster et al.(2008) that academic staff in Nigerian universities are not comparatively accessing e-resources in research, which may account to their low productive capacity internationally.

A study by Kirlidog and Bayir (2007) linked academic productivity with access and use of electronic resources. They attributed the low level of scientific publications in developing countries in relation to that of developed and industrialized nations essentially to inadequate access to scientific literature as typified by modern electronic resources. According to their study of productivity of Turkish universities between 1998 and 2003 using the Web of Science, the results showed comparative annual increase in quantity of publications originating from all Turkish institutions, but the increase was remarkable after 2000. Kirlidog and Bayir (2007: 104) concluded that "the sharp increase after 2000 is clearly related to access to scientific journals through ANKOS", and argued that many academics in Turkish universities, are benefiting extensively from electronic databases provided by ANKOS (Anatolian University Libraries Consortium). ANKOS is responsible for massive provision of electronic databases to all universities in Turkey; its mission is to provide researchers in all Turkish universities with access to electronic resources and global network in a cost-effective manner. Tenopir, Wilson, Vakkari, Talja and King (2008) in a survey of access and use of electronic resources in three countries: Finland, the U.S. and Australia; found that productivity was correlated with the use of e-resources in Finland and the U.S., but no correlation between the use of e-resources and productivity was found in Australia. In a specific terms, "in Finland, the total number of scholarly items published was significantly associated with the number of electronic article readings" by the academic staff (Tenopir et al., 2008: 7); and similar result was found in the U.S. The paper concluded that, it's appeared that, the correlation between use of electronic resources and academic productivity may vary from country to country. Vakkari (2008: 603) affirmed that "the use of e-resources and Internet-based tools seem to have a positive influence on scholars' publication productivity". Similarly, Atakan, Atilgan, Bayram, and Arlantekin (2008) asserted that there is a strong relationship between electronic journal usage and research activities in universities. In view of this, the puzzle that concerns the present study is, will the situation in Nigerian universities be similarly or different as reported in the literature above?

\section{Aim of the Study}

The aim of the paper was to investigate the effect of accessibility and utilization of electronic resources on productivity of academic staff in Nigerian universities. In other words, the paper aimed to determine if there is positive correlation between accessibility and utilization of electronic resources and productivity of academic staff in Nigerian universities. Thus, the following hypothesis was formulated to guide the study:

There is no significant correlation between accessibility and utilization of electronic information resources and productivity of academic staff in Nigerian universities.

The hypothesis was further formulated and tested at international level of research productivity thus:

There is no significant correlation between accessibility and utilization of electronic information resources and international productivity of academic staff in Nigerian universities.

\section{Research Methodology}

The survey method was used for the study with the questionnaire as instrument for data collection. Two Nigerian universities, University of Calabar and University of Ibadan were used in the survey. The designed questionnaire was divided into three sections: section one captured data on demographics of the respondents, section two dealt with the level of accessibility and utilization of electronic resources by respondents, and section three captured data on the productivity of respondents. Copies of the questionnaire were administered to 586 academic staff as respondents at the surveyed universities from July-August 2012; 324 copies of the questionnaire were completed by the respondents and 
retrieved by the researchers for data analysis. The response rate was $55.29 \%$ and was considered adequate for data analysis. Out of the 324 completed copies of the questionnaire, a breakdown showed that 173 copies were from the University of Calabar and 151 from the University of Ibadan respectively. The Statistical Package for Social Science (SPSS) was used for data analysis.

\section{Results of the Study}

\subsection{Demographic of the Respondents}

The results of the study revealed that the respondents were dominantly males $(70.7 \%)$ compared with $29.3 \%$ females. The distribution of the respondents by discipline showed that majority $(48.3 \%)$ were from the Faculty of Science, followed by Education (24.4\%), Agriculture (10.8\%), Arts (10.2\%) and Social Science $(9.9 \%)$. In terms of professional rank, respondents from the rank of senior lecturer received the highest responses of $37.3 \%$, lecturer $(30.9 \%)$, assistant lecturer $(14.2 \%)$, professor $(9.0 \%)$, and associate professor $(8.6 \%)$.

\subsection{Effect of Accessibility and Utilization of Electronic Resources on Productivity of Respondents}

The study sought to determine if there is positive effect between accessibility and utilization of electronic resources and productivity of academic staff in Nigerian universities. The respondents were asked to indicate their level of accessibility and utilization of electronic resources in research as well as their productivity in terms of national, international, and total productivity between January 2005 and July 2012. Correlation analysis of the effect of accessibility and utilization of electronic resources on productivity of the respondents at the surveyed universities is shown in Table 1. Correlation analysis as shown in Table 1 indicates that there was significant positive correlation between accessibility and utilization of electronic resources and productivity of academic staff at the surveyed universities $(r=0.135 ; \mathrm{p}=0.015)$. This implies that increase in access and use of electronic resources will lead to increase in productivity among the respondents in the survey Nigerian universities. Similar result was obtained when the hypothesis was tested at international level (Table 1) with $r=0.158$ and $p=0.004$. In other words, academic staff that frequently access and use electronic resources in research at the surveyed universities are internationally productive (or publish more articles in international journals) than those who do not or are accessing and using electronic resources less frequently.

Table 1. Correlation analysis between accessibility and utilization of e-resources and productivity.

\begin{tabular}{llll}
\hline & Accessibility & Total productivity & International productivity \\
\hline Accessibility Pearson correlation & 1 & 0.135 & 0.158 \\
Sig. (2 tailed) & & 0.015 & 0.004 \\
N & 324 & 324 & 324 \\
\hline
\end{tabular}

*Correlation is significant at the 0.05 level (2-tailed)

**Correlation is significant at the 0.01 level (2-tailed)

However, analysis of the results by university indicates that there was no significant correlation between accessibility and utilization of electronic resources and productivity of respondents at the University of Calabar $(r=0.074 ; \mathrm{p}=0.330)$ as shown in Table 2. Similarly, in terms of international productivity, it was found that there was no significant correlation between accessibility and utilization of eresources and international productivity of the respondents at the University of Calabar.
But in contrast, the results in Table 3 indicate that there was significant correlation between accessibility and utilization of electronic resources and productivity of respondents at the University of Ibadan $(\mathrm{r}=0.282 ; \mathrm{p}=0.000)$. It was also found that there was significant correlation between accessibility and utilization of electronic resources and international productivity of respondents at the University of Ibadan as shown in Table 3.

Table 2. Correlation analysis between accessibility and utilization of e-resources and productivity at the University of Calabar.

\begin{tabular}{llll}
\hline & Accessibility & Total productivity & International productivity \\
\hline Accessibility Pearson correlation & 1 & 0.074 & 0.103 \\
Sig. (2 tailed) & & 0.330 & 0.177 \\
$\mathrm{~N}$ & 173 & 173 & 173 \\
\hline
\end{tabular}

*Correlation is significant at the 0.01 level (2-tailed)

Table 3. Correlation analysis between accessibility and utilization of e-resources and productivity at the University of Ibadan.

\begin{tabular}{llll}
\hline & Accessibility & Total productivity & International productivity \\
\hline Accessibility Pearson correlation & 1 & 0.282 & 0.231 \\
Sig. (2 tailed) & & 0.000 & 0.004 \\
N & 151 & 151 & 151 \\
\hline
\end{tabular}

*Correlation is significant at the 0.01 level (2-tailed) 


\section{Discussion of Results}

The accessibility and utilization of electronic resources in universities for research purposes is becoming rife around the world. But in Nigeria, the level of accessibility and utilization of electronic resources is low when compared with that of developed countries due to lack of access to ICT infrastructural facilities. Foster et al., (2008) made a proposition that, academic staff in Nigerian universities will significantly increase their productivity if they join their counterparts in developed countries to access and use electronic resources in research. Interestingly, the results of the study revealed that there was a significant positive correlation between accessibility and utilization of electronic resources and productivity at the surveyed Nigerian universities. The implication of the results is that, increase in accessibility and utilization of electronic resources will lead to increase in productivity of academic staff in Nigerian universities. Furthermore, it was specifically found that accessibility and utilization of electronic resources has a positive effect on international productivity of academic staff at the surveyed Nigerian universities. The results of the survey align with that of Foster et al. (2008) and Kirlidog and Bayir (2007) that researchers in developing countries will be internationally productive if they have equitable access and use of electronic resources as their research tools. In Nigeria, NULIB (Nigerian University Libraries Consortium) and National Universities (NUC) are collaborating to provide access to relevant electronic resources in Nigerian universities as obtained in Turkish universities by ANKOS (Kirlidog \& Bayir, 2007). So far, NULIB and NUC have jointly provided access to EBSCO HOST database to Nigerian universities. It is therefore hoped that with the findings of this study and global impact of electronic resources on research, NULIB and NUC will increase their efforts to provide access to electronic resources across all disciplines in Nigerian universities.

However, analysis of the results by university revealed that the impact of electronic resources on productivity of academic staff varies between the two surveyed universities. From the results, it was found that, there was no significant correlation between accessibility and utilization of electronic resources and productivity of academic staff at the University of Calabar. But in contrast, the results of the study indicated that there was a positive correlation between accessibility and utilization of electronic resources and productivity of academic staff at the University of Ibadan. It is therefore evidenced from these results that there is a higher degree of accessibility and utilization of electronic resources at the University of Ibadan than at the University of Calabar. This implies that the level of investment on ICT facilities/electronic resources at the University of Ibadan is higher than at the University of Calabar. So, there is need for individual Nigerian universities to increase their level of investment on ICT facilities/electronic resources in order to promote efficiency in research and increase in productivity.

\section{Conclusion}

The digital revolution has brought a huge transformation in research in global perspective, as accessibility and utilization of electronic resources is reportedly impacting positively on research process of the academic staff, particularly in the developed countries. The present study sought to explore the effect of accessibility and utilization of electronic resources on productivity of academic staff in Nigerian universities. The finding of the study has revealed a positive correlation between accessibility and utilization of electronic resources on productivity of academic staff at the surveyed Nigerian universities $(r=0.135 ; p=0.015)$. This implies that increase in access and use of e-resources will lead to increase in productivity among academic staff at the surveyed universities. Furthermore, it was found that, there was a positive effect of accessibility and utilization on international productivity of academic staff at the surveyed Nigerian universities with $r=0.158$ and $p=0.004$. In other words, academic staff that frequently access and use e-resources in research publish more articles in international journals than those who do not. Hence, in view of the observed positive impact of e-resources on productivity; university managements, university librarians, National Universities Commission (NUC) and other stakeholders in Nigerian universities should intensify the process of effective ICT diffusion and provision of relevant eresources in Nigerian universities towards sustainable increase in productivity. This will also make academic staff in Nigerian universities to be globally competitive for journal space in international journals, and thus bridge the productivity gap between Nigerian universities and their counterparts in developed countries.

\section{References}

[1] Adeloye, A. (2000). The Information market in Nigeria. Journal of Information Science 26 (4): 282-285.

[2] Aina, L. O. (2012). The Information environment for agricultural stakeholders in Botswana. Information Development 28 (2): 149-159.

[3] Abrahams, L. Burke, M. \& Mouton, J. (2009/2010). Research productivity-visibility-accessibility and scholarly communication in Southern African universities. The African Journal of Information and Communication 10: 20-36.

[4] Al-Shanbari, H. \& Meadows, A. J. (1995). Problems of communication and information-handling among scientists and engineers in Saudi universities. Journal of Information Science 21 (6): 473-478.

[5] Ani, O. E, Esin, J. E. \& Inyang, S. O. (2003). Publication patterns and productivity of academic scientists: case study of University of Calabar - Nigeria. Global Journal of Humanities 2(1/2):66-70.

[6] Appleton, L. (2006). Perceptions of electronic library resources in further Eeducation. The Electronic Library 24 (5): 619-634. 
[7] Atakan, C., Atilgan, D., Bayram, O. \& Arlantekin, S. (2008). An evaluation of the second survey on electronic databases usage at Ankara University Digital Library. The Electronic Library 26 (2): 249-259.

[8] Bottle, R, Hossein, S, Bottle, A, \& Adesanya, O. (1994). The productivity of British, American and Nigerian chemists compared. Journal of Information Science 20(3): 211-215.

[9] Collazo-Reyes, F., Luna-Morales, M. E., Russell, J. M. \& Perez-Angon, M. (2011). Emergence and convergence of scientific communication in a developing country: Mexico (1990-1979). Proceedings of the ISSI 2011 Conference: $13^{\text {th }}$ International Conference of

[10] Costa, S. \& Meadows, J. (2000). The impact of computer usage on scholarly communication among social scientists. Journal of Information Science 26 (4): 255-262.

[11] Dadzie, P. S. (2005). Electronic resources: access and usage at Ashei University College. Campus Wide Information Systems 22(5): 290-297. Also Available at: http/www: emeraldinsight.com/1065-0741.htm. (Accessed 6.5.10).

[12] Duque, R. B., Ynalvez, M., Sooryamoorthy, R., Mbatia, P., Dzorgbo, D. \& Shrum, W. (2010). Collaboration paradox: scientific productivity, the internet and problems of research in developing areas. Available at http: wordsci.net/paradox.pdf. (Accessed 8 .5.10)

[13] Ellis, D. \& Oldman, H. (2005). The English literature researcher in the age of the internet. Journal of Information Science 3 (1): 29-36.

[14] Foster, K, Heppensta, R, Lazarz, C. \& Broug, E. (2008). Emerald academy 2008 authorship in Africa. Available at http://info.emeraldinsight.com/pdf/report.pdf/. ～(Accessed 20.3.09).

[15] Frankor, D. K., \& Akussah, H. (2012). Information use and policy decision making by district assembly members in Ghana. Information Development 28 (1): 32-42.

[16] Goel, K. (2002). Gender differences in publication productivity in psychology in India. Scientometrics 55(2): 243-258.

[17] Gupta, B. M., Kumar, S. \& Aggarwal, B. S. (1999). A Comparison of productivity of male and female scientists of CSIR. Scientometrics 45 (2): 269-289.

[18] Haridasan, S. \& Khan, M. (2009). Impact of e-resources by social scientists in National Science Documentation Centre (NASSDOC), India. The Electronic Library 27 (1): 117-133.

[19] Hoq, K. M. (2012). Role of information for rural development in Bangladesh: A Sector-wise review. Information Development 28 (1): 13-21.
[20] Kirlidog, M. \& Bayir, D. (2007). The effects of electronic access to scientific literature in the consortium of Turksih University Libraries. The Electronic Library 25 (1): 102-113.

[21] Lee, S. (2002). Electronic Collection Development: A Practical Guide. New York: Neal-Schuman Publishers INC.

[22] Moon, J., Hossain, M. D., Kang, H. G. \& Shin, J. (2012). Analysis of agricultural informatization in Korea: the government's role in bridging the digital divide. Information Development 28 (2): 102-116.

[23] Nworgu, B. G. (1991). Educational Research; Basic Issues and Methodology. Ibadan: Wisdom Publishers.

[24] Okafor, V. N. (2010). Research output of academics in the science and engineering faculties of the federal universities in Southern Nigeria. African Journal of Library, Archives and Information Science 20 (1): 41-51.

[25] Onyancha, O. B. (2008). Growth, productivity, and scientific impact of sources of HIV/AIDs research information, with focus on eastern and southern Africa. A Journal of AIDS Research 7(1): 55-70.

[26] Parameshwar, S. \& Patil, D. B. (2009). Use of the internet by faculty and research scholars at Gulbarga University Library. Library Philosophy and Practice. Available at: $\mathrm{http} / / /$ digitalcommons.unl.edu/cgi/viewcontent.cgi?article=12 68\&context=libphilprac\&sei. (Accessed 26.6.12).

[27] Sanz, E., Aragon, I. \& Mendez, A. (1995). The function of national journals in disseminating applied science. Journal of Information Science 21 (4): 319-323.

[28] Swain, D. K. (2010). Students' Keenness on Use of Eresources. The Electronic Library 28 (4): 580-591.

[29] Tenopir, C., Wilson, C. S., Vakkari, P., Talja, S. \& King, D. W. (2008). Scholarly e-reading patterns in Australia, Finland, and the United States: A Cross country comparison. World Library and Information Congress: $74^{\text {th }}$ IFLA General Conference and Council, 1014 August, Quebec, Canada. Available at http: //www.ifla.org/IV/ifla74/index.htm. (Accessed 10.6.11).

[30] Thanuskodi, S. (2012). Use of e-resources by post graduate engineering students with special reference to Sona College of Technology, Salem: A Survey. In: DK Swain (ed.) Electronic Age Librarianship. New Delhi: Ane Books PVT Ltd. 323-338.

[31] Vakkari, P. (2008). Perceived influence of the use of electronic information resources on scholarly work and publication productivity. Journal of the American Society for Information Science and Technology 59 (4): 602-612. 